\title{
UK Renal Registry 19th Annual Report: Appendix E Methodology for Estimating Catchment Populations of Renal Centres in the UK for Dialysis Patients
}

\section{Introduction}

Providing accurate centre-level incidence and prevalence rates for patients receiving renal replacement therapy (RRT) in the UK was limited until the 13th Annual Report by the difficulty in estimating the catchment population from which the RRT population was derived. One reason for this was that the geographical boundaries separating renal centres are relatively arbitrary and dependent upon a number of factors including referral practice, patient choice and patient movement. Previously, incidence and prevalence rates had been calculated at Local Authority/Primary Care Trust/Health Board level for which denominator data were available, but not at renal centre level.

UK Renal Registry (UKRR) annual reports prior to the 13th suggested an estimate of the size of the catchment populations. These were extrapolated figures originally derived from data in the 1992 National Renal Survey undertaken by Professor Paul Roderick.

The purpose of this appendix is to present an estimate of the dialysis catchment population for all renal centres in the UK. It also contains a methodological description and discussion of the limitations of these methods. Previous UKRR annual reports contained estimates for English renal centres using 2001 Census data and a similar methodology as outlined here [1]. For the 16th Annual Report the methodology was repeated using data from the 2011 Census in order to obtain more up to date estimates and also to include renal centres in Wales. For the 17th Annual Report, estimates for renal centres in Scotland and Northern Ireland were calculated thus completing full coverage of the UK.

\section{KARGER}

Fax +4161306 1234 E-Mail karger@karger.com www.karger.com/nef
C 2017 The UK Renal Registry

Published by S. Karger AG, Basel

This article is licensed under the Creative Commons AttributionNonCommercial-NoDerivatives 4.0 International License (CC BYNC-ND) (http://www.karger.com/Services/OpenAccessLicense). Usage and distribution for commercial purposes as well as any distribution of modified material requires written permission.

\section{Methods}

The UKRR database of the incident dialysis population between 1st January 2008 and 31st December 2012 was used to estimate the size of each renal centre's catchment population. This used the postcode and centre for each individual at the time of starting RRT on dialysis.

Polygons were constructed to define an area around the geographical location of each dialysis patient. The lines of the polygons, representing the boundaries between areas, were drawn such that they were equidistant between adjacent patients, creating a map of non-overlapping polygons covering the entire area of England, Northern Ireland, Scotland and Wales (the process was done separately for each country). This method produces Thiessen polygons which have the property that all locations within each polygon share the same nearest dialysis patient [2].

The polygons of all patients starting at the same renal centre were combined to create the catchment area for that centre. The catchment area for one centre might comprise multiple unconnected polygons as a result of adjacent patients attending different renal centres. The Office for National Statistics (ONS) map of 2011 Census merged wards contains population estimates for England and Wales divided into 8,546 wards. The Northern Ireland Statistics and Research Agency (NISRA) published population estimates based on the 2011 Census for 4,537 geographical regions referred to as Small Areas. The General Register Office for Scotland published 2011 population estimates at 6,505 data zone level areas. Wards, Small Areas and data zones will collectively be referred to as wards in the following paragraph.

UK Renal Registry, Southmead Hospital, Southmead Road, Bristol, BS10 5NB, UK

Email: renalregistry@renalregistry.nhs.uk 
The wards were overlaid on the map of renal centre catchment areas, enabling the proportion of each ward's area covered by each of the renal centre catchment areas to be calculated. Each ward's population was then allocated to the renal centres in proportions equal to the proportions of the overlaid areas. Summing these proportions of populations across all of the wards for each renal centre produced the estimates of the total catchment population for each centre.

\section{Results}

The estimated dialysis catchment populations for renal centres in England, Wales, Northern Ireland and Scotland are shown in Tables E.1, E.2, E.3 and E.4 respectively.

Table E.1. Estimated dialysis catchment populations of English renal centres based upon 2011 Census ONS Census ward population estimates (rounded to nearest 1,000 )

\begin{tabular}{lrlr}
\hline Centre & Estimate & Centre & Estimate \\
\hline B Heart & 738,000 & Leeds & $1,670,000$ \\
B QEH & $1,699,000$ & Leic & $2,436,000$ \\
Basldn & 415,000 & Liv Ain & 484,000 \\
Bradfd & 652,000 & Liv RI & $1,000,000$ \\
Brightn & $1,297,000$ & M RI & $1,531,000$ \\
Bristol & $1,439,000$ & Middlbr & $1,004,000$ \\
Camb & $1,158,000$ & Newc & $1,121,000$ \\
Carlis & 321,000 & Norwch & 787,000 \\
Carsh & $1,913,000$ & Nottm & $1,088,000$ \\
Chelms & 510,000 & Oxford & $1,690,000$ \\
Colchr & 299,000 & Plymth & 470,000 \\
Covnt & 892,000 & Ports & $2,024,000$ \\
Derby & 703,000 & Prestn & $1,493,000$ \\
Donc & 410,000 & Redng & 910,000 \\
Dorset & 862,000 & Salford & $1,490,000$ \\
Dudley & 442,000 & Sheff & $1,372,000$ \\
Exeter & $1,089,000$ & Shrew & 501,000 \\
Glouc & 587,000 & Stevng & $1,204,000$ \\
Hull & $1,020,000$ & Sthend & 317,000 \\
Ipswi & 399,000 & Stoke & 890,000 \\
Kent & $1,224,000$ & Sund & 618,000 \\
L Barts & $1,830,000$ & Truro & 413,000 \\
L Guys & $1,082,000$ & Wirral & 572,000 \\
L Kings & $1,171,000$ & Wolve & 669,000 \\
L Rfree & $1,518,000$ & York & 492,000 \\
L St G & 797,800 & England & $\mathbf{5 3 , 3 9 9 , 0 0 0}$ \\
L West & $2,399,000$ & & \\
\hline Contanc & 5 & & \\
\hline
\end{tabular}

Contains National Statistics data (C) Crown copyright and database right 2013

Contains Ordnance Survey data (C) Crown copyright and database right 2013
Table E.2. Estimated dialysis catchment populations of Welsh renal centres based upon 2011 Census ONS Census Ward population estimates (rounded to nearest 1,000 )

\begin{tabular}{lrlr}
\hline Centre & Estimate & Centre & \multicolumn{1}{c}{ Estimate } \\
\hline Bangor & 218,000 & Swanse & 885,000 \\
Cardff & $1,420,000$ & Wrexm & 240,000 \\
Clwyd & 190,000 & Wales & $\mathbf{2 , 9 5 3 , 0 0 0}$ \\
\hline
\end{tabular}

Contains National Statistics data (C) Crown copyright and database right 2013

Contains Ordnance Survey data (C) Crown copyright and database right 2013

Table E.3. Estimated dialysis catchment populations of renal centres in Northern Ireland based upon 2011 Census NISRA Small Area population estimates (rounded to nearest 1,000)

\begin{tabular}{lllr}
\hline Centre & Estimate & Centre & \multicolumn{1}{c}{ Estimate } \\
\hline Antrim & 295,000 & Ulster & 266,000 \\
Belfast & 637,000 & West NI & 352,000 \\
Newry & 261,000 & N Ireland & $\mathbf{1 , 8 1 1 , 0 0 0}$
\end{tabular}

Source: NISRA: Website: www.nisra.gov.uk

Table E.4. Estimated dialysis catchment populations of renal centres in Scotland based upon 2011 Census NRS data zone area population estimates (rounded to nearest 1,000)

\begin{tabular}{lllr}
\hline Centre & Estimate & Centre & \multicolumn{1}{c}{ Estimate } \\
\hline Abrdn & 600,000 & Glasgw & $1,624,000$ \\
Airdrie & 552,000 & Inverns & 270,000 \\
D \& Gall & 148,000 & Klmarnk & 361,000 \\
Dundee & 463,000 & Krkcldy & 317,000 \\
Edinb & 964,000 & Scotland & $\mathbf{5 , 3 0 0 , 0 0 0}$ \\
\hline
\end{tabular}

Contains NRS data (C) Crown copyright and database right 2014

Contains Ordnance Survey data (C) Crown copyright and database right 2014

\section{Discussion}

These results show estimates for the size of the catchment areas for each of the renal centres in the UK.

There are some limitations to these results. The main one is that the ward/small area/data zone allocated to each renal centre was based upon dialysis patients only. Therefore it is possible that non-dialysis patients may come from a different catchment population. This is more likely where a renal centre provides specialist services and especially likely for patients undergoing renal transplantation. The catchment population for renal transplant patients will depend largely upon the distribution of workload between the referral centre and 
the transplanting centre for pre-transplant work-up, donor nephrectomy work-up and post-transplant care (including if and when care is returned to the referring centre).

Despite the limitations, this is the most valid methodology to date to estimate the size of the catchment populations for renal centres in the UK. The results of this analysis allows the UKRR to calculate estimates of the incidence and prevalence rates of RRT at renal centre level, rather than only at CCG/HB level.

These results also provide other opportunities for the study of the catchment populations. The ONS provides data on gender, age and ethnicity of the population at ward level. It should be possible to use this information to consider centre differences in the demographics of patients commencing or receiving RRT with adjustment for the catchment population characteristics.

\section{Acknowledgements}

Thanks are expressed to Andrew Judge for calculating these catchment populations for the UK Renal Registry.

\section{References}

1 Judge A, Caskey FJ, Welton NJ, Ansell D, Tomson CR, Roderick PJ, Ben-Shlomo Y: Inequalities in rates of renal replacement therapy in England: does it matter who you are or where you live? Nephrol Dial Transplant. 2012 Apr;27(4):1598-607 Nephron Dial Transplant. 2012 Apr:27(4):1598-607. doi: 10.1093/ndt/gfr466. Epub 2011 Aug 30

2 Boots BN: Voronoi (Thiessen) Polygons (Concepts and Techniques in Modern Geography); Norwich: Geo Books, 1986 
